Article available at nttp://www.parasite-journal.org or nttp://dx.dol.org/10.1051/parasite/200108s2141

\title{
THE USE OF A SYNTHETIC ANTIGEN FOR THE SEROLOGICAL DIAGNOSIS OF HUMAN TRICHINELLOSIS
}

\author{
BRUSCHI F.*, MORETTI A.**, WASSOM D.*** \& PIERGILI FIORETTI D.**
}

Summary :

Hosts infected with Trichinella produce antibodies specific for an epitope common to the TSL-I family antigens. This epitope contained uncommon terminal 3, 6-dideoxy-D-arabinohexose /so called tyvelose) residues. The disaccharide moiety was synthesized and an immunodiagnostic assay was developed, which was specific and sensitive in swine trichinellosis. We aimed to verify the specificity and sensitivity of this immunodiagnostic test in human trichinellosis. 15 sera from normal subjects, 12 from patients with other parasitic diseases and 50 from trichinellosis patients were tested. Indirect enzyme linked immunosorbent assay (ELISA) for specific $\lg G$ and an amplified ELISA for specific lgE were performed using $\beta$-tyvelose-GalNAc-bovine serum albumin (BSA) disaccharide conjugate or $T$. spiralis muscle larvae excretory/secretory (E/S) products, as antigens. Neither control sera nor other parasitic infection sera resulted positive both for $\lg G$ and $\lg E$ when synthetic or $E / S$ antigens were used. In trichinellosis patient sera, specific lgG were present in $100 \%$ of cases, irrespective of the antigen used, but whereas specific lgE were detected in $78 \%$ using $E / S$ antigens, a $100 \%$ positivity rate was obtained, using the $\beta$-tyvelose- BSA conjugate.

KEY WORDS : $\beta$-tyvelose, human trichinellosis, lgG, lgE, diagnosis.

T richinellosis is a relevant zoonotic disease, with a worldwide distribution, resulting from ingestion of raw or undercooked meat containing infecting larval stages of nematodes of Trichinella species (Bruschi \& Murrell, 1999).

One of the biggest problems of the serological diagnosis of human trichinellosis is the lack of availability of an antigen, to be used in immunoenzymatic tests, which does not cross react with other infectious agents and in particular with other nematodes, especially in those geographical regions where infections caused by the latter are endemic (Murrell \& Bruschi, 1994). It has been shown that hosts infected with Trichinella (regardless of the species) produce antibo-

\footnotetext{
* Dipartimento di Patologia Sperimentale, B.M.I.E., Università di Pisa, Via Roma 55, 56126 Pisa, Italy.

** Dipartimento di Scienze Biopatologiche Veterinarie, Università di Perugia, Via S. Costanzo 4, 06100 Perugia, Italy.

${ }^{* * *}$ Heska Corporation, 1825 Sharp Point Drive, Fort Collins, Colorado, USA.

Correspondence: F. Bruschi.

Tel.: +39(050)554851 - Fax: +39(050)554929.

e-mail: fbruschi@med.unipi.it
}

dies specific for the carbohydrate epitope which is common to the TSL-1 (T. spiralis antigens-group 1) family antigens (Appleton et al., 1991), produced by L1 stichosome (Silberstein \& Despommier, 1985), a specialized secretory organ containing cells called stichocytes. This epitope was characterized and contained uncommon terminal 3, 6-dideoxy-D-arabinohexose (so called tyvelose) residues (Wisnewski et al., 1993). Tyvelose residues were also described in some Gram-negative bacterial lipopolysaccharides and in Ascaris eggs, but the configuration of tyvelose in $\beta$ is peculiar to Trichinella. The glycans present in the TSL-1 family antigens are represented by tri- and tetra-antennary structures containing the tyvelose and are likely to be highly immunogenic (Reason et al., 1994). Furthermore, the disaccharide moiety was sinthesized and an immunodiagnostic assay was developed for the diagnosis of swine trichinellosis, resulting specific and sensitive (Wisnewski et al., 1997). The aim of our study was to verify the specificity and sensitivity of this immunodiagnostic test in human trichinellosis.

\section{MATERIALS AND METHODS}

SERA

Difteen sera from trichinellosis free subjects (normal subjects), 12 from other parasitic disease 1 (caused by both protozoa and helminths) patients with a clinical and serological diagnosis, and 50 from trichinellosis patients, resulted positive in indirect immunofluorescence, were used. The trichinellosis patients were infected during an outbreak which occurred in Central Italy in 1988 , caused by $T$. britovi (Frongillo et al., 1992).

\section{ANTIGENS}

Synthetic antigen

$\beta$-tyvelose-GalNAc-bovine serum albumin (BSA) disaccharide conjugate, free of $\alpha$-tyvelose was kindly provided by Heska Corporation, Fort Collins, Colorado. 


\begin{tabular}{lcccc}
\hline & & $\begin{array}{c}\text { IgG } \\
\text { anti-sugar-conjugated } \\
\text { albumin }\end{array}$ & IgE anti-E/S & $\begin{array}{c}\text { IgE } \\
\text { anti-sugar-conjugated } \\
\text { albumin }\end{array}$ \\
\hline Controls $(\mathrm{n}=15)$ & $0.054 \pm 0.02^{\circ}(0)^{*}$ & $0.061 \pm 0.01(0)$ & $0.055 \pm 0.01(0)$ & $0.049 \pm 0.01(0)$ \\
Other parasitic diseases $(\mathrm{n}=12)$ & $0.064 \pm 0.02(0)$ & $0.058 \pm 0.03(0)$ & $0.060 \pm 0.01(0)$ & $0.045 \pm 0.02(0)$ \\
\hline
\end{tabular}

- mean optical density \pm s.d. obtained at 1:20 dilution of the sera.

* positivity rates are shown in parentheses.

Table I. - Results obtained with controls.

\begin{tabular}{|c|c|c|c|c|}
\hline Sera & IgG anti-E/S & $\begin{array}{c}\text { IgG } \\
\begin{array}{c}\text { anti-sugar-conjugated } \\
\text { albumin }\end{array} \\
\end{array}$ & IgE anti-E/S & $\begin{array}{c}\text { IgE } \\
\begin{array}{c}\text { anti-sugar-conjugated } \\
\text { albumin }\end{array} \\
\end{array}$ \\
\hline Trichinellosis patients $(n=50)$ & $0.440 \pm 0.01^{\circ}$ & $0.452 \pm 0.01$ & $0.070 \pm 0.016^{*}$ & $0.296 \pm 0.02$ \\
\hline $1: 20$ & - & - & - & $3(6)$ \\
\hline $1: 40$ & - & - & $17(34)$ & $16(32)$ \\
\hline $1: 80$ & $8(16)^{* *}$ & $8(16)$ & $18(36)$ & $25(50)$ \\
\hline $1: 160$ & $24(48)$ & $24(48)$ & $4(8)$ & $6(12)$ \\
\hline $1: 320$ & $18(36)$ & $18(36)$ & - & - \\
\hline Total & $(100)$ & $(100)$ & (78) & (100) \\
\hline
\end{tabular}

- Mean optical density \pm s.d. obtained at 1:20 dilution of the sera.

* At 1:20 dilution, using E/S antigens IgE were not detected.

** Positivity rates are shown in parentheses.

Table II. - Results obtained with patients.

$\mathrm{E} / \mathrm{S}$ antigens

E/S antigens were collected after incubation of $T$. spiralis $\mathrm{L} 1$ larvae at $37^{\circ} \mathrm{C}$ in MEM-Eagle (Gibco, Paisley, Scotland). The supernatant, collected after centrifugation, was filtered through Millipore filters $(0.22 \mu)$, concentrated with $7.5 \%$ PEG 6,000 to a final concentration of $700 \mu \mathrm{g} / \mathrm{ml}$ and stored at $-80^{\circ} \mathrm{C}$ until use.

\section{INDIRECT ELISA}

Indirect ELISA for the detection of specific IgG (Bruschi et al., 1990) were performed. $125 \mathrm{ng}$ of synthetic antigen, dissolved in Tris-EDTA-NaCl buffer, $\mathrm{pH}$ 7.3, or $100 \mu \mathrm{g} / \mathrm{ml}$ of E/S antigens were added to each well, after that plates were stored at $+4^{\circ} \mathrm{C}$ overnight.

After washing with phosphate buffer saline, $\mathrm{pH} 7.2$ with $0.05 \%$ Tween, human sera were added at different dilutions in phosphate buffer saline (PBS)-BSA. The presence of antibodies were revealed using a peroxidase-conjugated anti human IgG (Sigma St. Louis, Mo) and orthophenylendiamine (Sigma St. Louis, Mo) and hydrogen peroxide as substrate. The reaction was stopped after 15 min. with $\mathrm{H}_{2} \mathrm{SO}_{4} 0.5 \mathrm{M}$ and reading was performed at $492 \mathrm{~nm}$.

\section{AMPLIFIED ELISA}

An amplified ELISA for specific IgE previously described (Tassi et al., 1990; Piergili-Fioretti et al., 1992) was performed.

\section{RESULTS}

7 he results show that neither control sera nor other parasitic infection sera resulted positive in any case for both IgG and IgE. when synthetic or $\mathrm{E} / \mathrm{S}$ antigens were used (Table I). In trichinellosis patient sera specific IgG were present in $100 \%$ of cases, irrespective of the antigen used, but whereas specific IgE were detected in $78 \%$ using $\mathrm{E} / \mathrm{S}$ antigens, a $100 \%$ positivity rate was obtained, using the $\beta$-tyvelose-GalNac BSA conjugate (Table II).

\section{DISCUSSION}

$T$ he parasitic nematode Trichinella produces a great amount of proteins able to induce a strong humoral response in infected hosts (Silberstein \& Despommier, 1985). Among them the TSL-1 family antigens play a crucial role in host-parasite relations and despite the fact that they represent only $3 \%$ of total protein present in muscle larvae, between 26 and $86 \%$ of all Trichinella-specific antibodies present in an infected host serum reacts with the carbohydrate common to these proteins, $\beta$-tyvelose (Denkers et al. 1990, 1991). Furthermore, Denkers et al. (1991) have clearly shown the incapability of other helminthic antigens to inhibit the binding of a carbohydrate epitope- 
specific monoclonal antibody with TSL- 1 antigens, suggesting the peculiarity of this epitope present in Trichinella. The absence of positive results observed in sera from other parasite infected subjects is in line with this observation. All trichinellosis patient sera reacted with $\beta$-tyvelose-conjugated albumin as well as with $\mathrm{E} / \mathrm{S}$ antigens. Considering that sera evaluated were from patients infected with T. britovi, our results confirm the existence of cross-reactions between the TSL-1 antigens from different Trichinella species (Gamble, 1994).

Our results show that trichinellosis patients produce not only IgG (even if at a lesser extent) but also IgE specific for the $\beta$-tyvelose epitope. This is the first observation in humans to our knowledge but the meaning in the light of host-parasite relations is far to be clarified. It is noteworthy that using only synthetic antigen we obtained, by an amplified ELISA, a $100 \%$ sensitivity for specific IgE, which was not even approached using $\mathrm{E} / \mathrm{S}$ antigen ( $78 \%$ ).

The availability of an antigen which is not responsible for false positive reactions represents the gold standard for a serological test, particularly in case of parasitic infection diagnosis where cross-reactions are very common. The specificity of the synthetic antigen used in our study is of importance as it can be used to confirm trichinellosis and rule out cross reactions.

\section{ACKNOWLEDGEMENTS}

The authors are grateful to Naomi Mulonzia for reading the manuscript.

\section{REFERENCES}

Appleton J.A., Bell R.G., Homan W. \& van Knapen F. Consensus on Trichinella spiralis antigens and antibodies. Parasitology Today, 1991, 7, 190-192.

Bruschi F. \& Murrell K.D. Trichinellosis. in: Tropical Infectious Diseases. Principles, Pathogens \& Practice. Guerrant R.L., Walker D.H., Weller P.F. (eds). Churchill-Livingstone, Philadelphia, PA, 1999, vol. 2, 917-925.

Bruschi F., Tassi C. \& Pozio E. Parasite specific antibody response in Trichinella sp. 3 human infection: a follow up to one year. American Journal of Tropical Medicine and Hygiene, 1990, 43, 186-193.

Denkers E.Y., Wassom D.L. \& Hayes C.E. Characterization of Trichinella spiralis antigens sharing an immunodominant carbohydrate-associated determinant distinct from phosphorylcholine. Molecular and Biochemical Parasitology, 1990, 41, 241-250.

DENKERS E.Y., HAYES C.E. \& WASSOM D.L. Trichinellas spiralis: influence of an immunodominant carbohydrate-associated determinant on the host antibody response repertoire. Experimental Parasitology, 1991, 72, 403-410.
Frongillo F., Balzelli B., Pozio E., Crapa G., Di Giuli C., SanTIROCCHI M. \& Di LEONARDO F. Report of an outbreak of human trichinellosis in central Italy. European Journal of Epidemiology, 1992, 8, 283-288.

GAMBLE H.R. Larval (L1) antigens for the serodiagnosis of trichinellosis in swine and other species, in: Trichinellosis. Campbell W.C., Pozio E. \& Bruschi F. (eds), ISS Press, Rome, 1994, 323-328.

Murrell K.D. \& Bruschi F. Clinical trichinellosis, in: Progress in Clinical Parasitology, Sun T. (ed), CRC Press, Boca Raton, Fl. 1994, 117-150.

Piergili-Fioretti D., Moretti A., Tassi C. \& Bruschi F. Specific IgE detected by an amplified ELISA method in human toxocariasis. Clinical Chemistry and Enzymology Communications, 1992, 4, 263-269.

Reason A.J., Ellis L.A., Appleton J.A., Wisnewski N., Grieve R.B., Mc NeIl M. et al. Novel tyvelose-containing tri- and tetra-antennary $\mathrm{N}$-glycans in the immunodominant antigens of the intracellular parasite Trichinella spiralis. Glycobiology, 1994, 5, 593-603.

SilbersteIn D.S. \& Despommier D.D. Effects on Trichinella spiralis of host responses to purified antigen. Science, 1985, 227, 948-950.

TASsi C., Sparvoli M. \& BrusChi F. Specific and total IgE in human trichinellosis infection. Use of an amplified ELISA system. Clinical Chemistry and Enzymology Communications, 1990, 3, 81-88.

Wisnewski N., McNeil M., Grieve R.B. \& Wassom D.L. Characterization of novel fucosyl- and tyvelosyl-containing glycoconnjugates from Trichinella spiralis muscle stage larvae. Molecular and Biochemical Parasitology, 1993, 61, 25-36.

Wisnewski N., Zhang J., Bundle D.R. \& Wassom D.L. Use of a novel synthetic $\beta$-tyvelose-GalNac neoglycan in serological detection of Trichinella spiralis infection, in: Trichinellosis ICT9, Ortega-Pierres G., Gamble H.R., van Knapen F. \& Wakelin D. (eds), CINVESTAV, Mexixo, 1997, 463-468. 